$\sqrt{B}$

J. Bio-Sci. 23: 47-55, 2015

ISSN 1023-8654

http://www.banglajol.info/index.php/JBS/index

\title{
ANTIMICROBIAL ACTIVITY OF TAMARINDUS INDICA L. AGAINST BACTERIA CAUSING URINARY TRACT INFECTION
}

\author{
K Biswas and SN Sinha* \\ Environmental Microbiology Research Laboratory, Department of Botany, University of Kalyani, West \\ Bengal, India
}

\begin{abstract}
Urinary tract infection (UTI) is a common bacterial infection known to affect the different parts of the urinary tract of human which is a great menace for the last decade. Various medicinal plants have been reported for treating infectious diseases including UTI due to their fewer side effects and reduced toxicity. The present study was to investigate the antibacterial activity of Tamarindus indica against UTI causing pathogens. Bacteria were isolated from the UTI infected women patients and characterized by using biochemical and morphological methods. Acetonic, methanolic and chloroform leaf extracts were used to evaluate their antibacterial activity against the bacteria isolated from UTI infected patients and the zones of inhibitions were measured. Four bacteria viz. Escherichia coli, Pseudomonas aeruginosa, Klebsiella sp. and Enterococcus sp. were isolated from 60 urine samples infected with UTI. Regarding antibacterial susceptibility test ampicillin showed lowest degree of MIC against Pseudomonas aeruginosa and highest degree of MIC against Klebsiella sp. Acetone extract of Tamarindus indica leaves showed highest antibacterial activity against $E$. coli $(22.5 \mathrm{~mm})$. Methanol extract showed highest activity against Pseudomonas aeruginosa $(21.4 \mathrm{~mm})$ and chloroform extract showed highest activity against Klebsiella sp. $(6.2 \mathrm{~mm})$. Different phytochemicals found in the plant extract were alkaloids, tannins, flavonoids, sesquiterpenes, carbohydrates, saponins, phlobatannins and anthocyanins.
\end{abstract}

Key words: Antibacterial activity, Tamarindus indica, urinary tract infection

\section{Introduction}

Apart from respiratory infections, urinary tract infection (UTI) is most common type of infection which begins in the urinary system. Kidneys, ureters, urinary bladder and the urethra are part of the urinary tract system (Geetha et al. 2011). Women are infected more to UTIs than men for anatomical reasons because woman's urethra is shorter, so bacteria quicker access to the bladder and the urethral opening of women is very close to the anus and vagina for sources of bacteria (Schappert and Rechtsteiner 2008). Nearly 95\% of UTI infections are caused by E. coli (Kebira et al. 2009). Other microorganisms responsible for UTI infections are Klebsiella, Pseudomonas, Enterococcus, Enterobacter, Proteus, Staphylococcus, Mycoplasma, Chlamydia, Serratia and Neisseria sp. (Sethi and Gupta 2013). Some potent antibiotics are available for the treatment of UTI, but increasing drug resistance among microbes has made therapy of UTI difficult because bacteria have the genetic potentiality to transfer and acquire resistance to antibiotic, as well as drugs (Srinivasan et al. 2001a).

For the last few decades it is an important job for researchers to find out alternative medicine to prevent UTI infections. Medicines from plant origin have enormous therapeutic potential against microorganisms. Throughout the history, plants have been a valuable resources of medicine (Thomson 1978, Stockwell 1988) and $70-90 \%$ of the rural population of the world still use herbal remedies for mental and physical health by

*Author for correspondence: sinhasn62@yahoo.co.in 
preventing or treating illness (Lai and Roy 2001). Plants provide a good deal of bioactive components which have benefited human in various ways, including remedy of diseases (Elaine et al. 2002).

Tamarindus indica L. (Tamarind) is a member of the family leguminosae with subfamily caesalpiniaceae (Khanzada et al. 2008). It is found in almost all tropical countries, like India, Africa, Caribbean, South America etc. Tamarind has been used as a medicinal plant from long time; fruits of this plant are the most important part which has often been reported as therapeutic in several pharmacopoeias. The leaves have preventive activity which is due to the presence of polyhydroxylated compounds with majority possessing flavonolic nature (Joyeux et al. 1995). Good levels of fat, protein, fiber and few vitamins such as niacin, thiamine, riboflavin, ascorbic acid and $\beta$-carotene are present in the leaves of this plant (El-Siddig et al. 2006). Phenols were, separated from aqueous extract of $T$. indica leaf as active compounds against $B$. subtilis cultures, but not against other microorganisms. On the other hand, the essential oil exhibited a good antimicrobial spectrum when pure but its relative low concentrations in common folk preparations do not allow for any good activity in these extracts (Escalona-Arranz et al. 2010). Ethanolic and aqueous (hot and cold) extracts of Tamarindus indica leaves were tested in vitro antibacterial activity against 13 Gram negative and $5 \mathrm{Gram}$ positive bacterial strains using agar well diffusion and macro broth dilution techniques, simultaneously. The cold water extract against $95.5 \%$ of the test bacterial strains; and the hot water and ethanolic extracts against $90.9 \%$ and $86.4 \%$, respectively showed antibacterial activity. The minimum inhibitory concentrations (MIC) ranged from $7.81 \mathrm{mg} / \mathrm{mL}$ against Bacillus subtilis ATCC 6051 to $31.25 \mathrm{mg} / \mathrm{ml}$ against Escherichia coli ATCC 11775; and the minimum bactericidal concentration (MBC) ranged from 125 $\mathrm{mg} / \mathrm{ml}$ against Pseudomonas aeruginosa ATCC 10145 to $250 \mathrm{mg} / \mathrm{ml}$ against Bacillus subtilis ATCC 6051 (Nowdo et al. 2011). Flavanoidal glycosides identified as major compound and using the total ion chromatography (TIC) two major compounds were identified as orientin and vitexin (Gumgumjee et al. 2012). The objective of the present work to isolate bacteria from urinary tract infected patient and also evaluate the antibacterial activity of $T$. indica against isolated UTI pathogens.

\section{Materials and Method}

\section{Isolation and identification of bacteria from UTI infected patients}

The bacteria present in urine samples of UTI infected women patients were cultured in the HiCrome UTI Agar. It is a differential medium recommended for presumptive identification of microorganisms mainly causing urinary tract infections. The isolated bacterial species was identified by morphological, physiological and biochemical tests (Holt et al. 1994).

\section{Detection of susceptibility to antibacterial agents}

From the identified causative agent, highly resistant species was selected by performing antibiotic susceptibility test against 5 different antibiotics that are ampicillin, chloramphenicol, ciprofloxacin, streptomycin and amoxicillin (Doughari 2006). Isolates were inoculated in peptone water and incubated in $37^{\circ} \mathrm{C}$ for $18-24 \mathrm{~h}$. Next, they were re-cultured in broth and their turbidity compared to $0.5 \mathrm{Mcfarland}$ standard solutions. More ever, new cultures were plated on Mueller-Hinton agar by swabbing. After drying for about 5$10 \mathrm{~min}$, Plates were incubated for about $10-15 \mathrm{~min}$ at $37^{\circ} \mathrm{C}$. Furthermore, interested antibiotic discs were adjusted on cultured plates using sterile forceps and incubated as inverted for $24 \mathrm{~h}$ at $37^{\circ} \mathrm{C}$.

\section{Collection of plant materials}

Leaves of Tamarindus indica were collected from Kalyani, West Bengal, India. Leaves of the plant was washed with running water, dried in shade at room temperature, ground to powder and stored in air tight bag after drying at low temperature. 


\section{Preparation of plant extracts}

Fifty grams of air-dried leaves of Tamarindus indica was grinded to powder and $5 \mathrm{~g}$ of plant powder was dissolved in known amount of various organic solvents (chloroform, methanol, acetone and aqueous) and kept for $24 \mathrm{~h}$ at room temperature with continuous shaking. The content was filtered to obtain clear decoction. Each preparation was filtered through a Whatman No. 1 filter paper and filtrate evaporated to dryness in a steady air current after which all extracts were stored in a sterile container and stored at room temperature (Saeed and Tariq 2008).

\section{Assaying extracts for antibacterial activity}

Antibacterial activity assay of different solvent extracts of the plants were done using the standard agar well diffusion technique. The test bacterial inoculam was standardized by McFarland Nephelometry (NCCLS 1993). The counts of Gram positive bacteria were adjusted to $1.0 \times 10^{6} \mathrm{CFU} / \mathrm{ml}$ and counts of Gram negative bacteria to $5 \times 10^{5} \mathrm{CFU} / \mathrm{ml}$ (NCCLS 1993). A $100 \mu \mathrm{l}$ volume of the standardized test bacterial suspension was seeded and spread uniformly onto each sterile Mueller Hinton agar (MHA) plate so that a confluent growth of bacteria was obtained. The petri dishes were allowed to dry and a sterile $6.0 \mathrm{~mm}$ diameter cork borer was used for making wells in the agar plates. The extracts were reconstituted with sterile distilled water to obtain a concentration of $62.5 \mathrm{mg} / \mathrm{ml}$; and $100 \mu \mathrm{l}$ of this was introduced in wells triplicate on the MHA plates. The plates were allowed to stand for $2 \mathrm{~h}$ at room temperature for diffusion and finally incubated at for $24 \mathrm{~h}$ at $37^{\circ} \mathrm{C}$. The inhibition zone diameter was measured.

\section{Determination of minimum inhibitory concentration}

The minimum inhibitory concentration of different extracts of leaf of $T$. indica $L$. was determined against selected bacteria separately. Concentration ranging from $300 \mu \mathrm{g} / \mathrm{ml}$ to $1 \mathrm{mg} / \mathrm{ml}$ of leaf extracts was prepared and $500 \mu \mathrm{l}$ of each dilution was incubated with $5 \mathrm{ml}$ of Mueller Hinton Broth containing $0.1 \mathrm{ml}$ of bacterial suspension at $37^{\circ} \mathrm{C}$ for 24 hours. After incubation the tubes were examined for bacterial growth by observing turbidity. The MIC was determined as minimum concentration that showed no visible growth. The experiment was carried out in triplicates. For the macro-broth dilution technique, a $100 \mu$ volume of each dilution of the extract was introduced into duplicate tubes of $2.0 \mathrm{ml}$ Mueller Hinton broth (MHB) seeded with $100 \mu$ lof the standardized suspension of the test bacterial strain. Incubation was at $37^{\circ} \mathrm{C}$ for $24 \mathrm{~h}$; and MIC was taken as the lowest concentration of the extract that made the culture show no visible growth.

The minimum bactericidal concentration was measured by $2 \mathrm{~mm}$ diameter agar disc cut out from the inhibition zone of the last three consecutive wells in each dilution showing inhibition was inoculated into a fresh sterile nutrient broth medium. The broth cultures were incubated at $37^{\circ} \mathrm{C}$ for $24 \mathrm{~h}$ after which $100 \mu \mathrm{l}$ was spread over a fresh sterile MHA. The MHA culture was in turn incubated at $37^{\circ} \mathrm{C}$ for $24 \mathrm{~h}$ and the least concentration of the extract showing no growth was taken as the MBC.

\section{Phytochemical screening}

Preliminary phytochemical analysis was carried out using standard protocol for determination of phytoconstituents: alkaloids, tannins, saponins, reducing sugars, anthocyanins, flavonoids, carbohydrates, terpenoids, cardiac glycosides, sesquiterpenes and phlobatannins as directed by references (Harborne 1998). 


\section{Results}

Sixty urine samples were collected from women patient who are suffered for UTI from JNM Hospital, Kalyani, West Bengal, India. E. coli was responsible 39 patient followed by Pseudomonas aeruginosa (18.18\%) and Klebsiella sp. (11.95\%). UTI causing gram positive bacteria, Enterococcus sp., is found only in 1 patient out of 60 patients (Fig. 1).

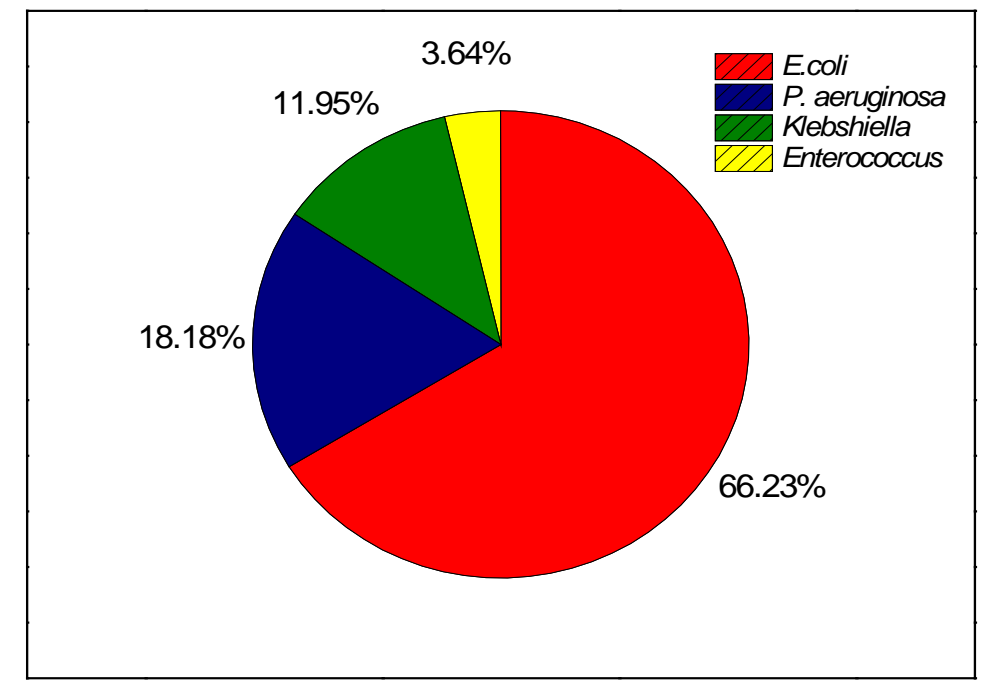

Fig. 1. Distribution of UTI causing pathogens.

All the tested bacteria of same species gave similar characteristics. Urine samples were cultured in UTI agar media. Then it is incubated at $37^{\circ} \mathrm{C}$ for $24 \mathrm{hrs}$ and isolated by seen their colony characteristics (Table 1).

Table 1. Cultural characteristics of UTI pathogens.

\begin{tabular}{lcc}
\hline Name of bacteria & Type of growth & Colour of colony \\
\hline Escherichia coli & Luxuriant & Purple \\
Pseudomonas aeruginosa & Do & Colourless \\
Klebsiella sp. & Do & Blue to purple, mucoid \\
Enterococcus sp. & Do & Blue, small
\end{tabular}

All of the presumptive isolates were sub-cultured and assessed for their morphological, physiological and biochemical characteristics (Table 2). 
Table 2. Identification of isolated microbe using biochemical test.

\begin{tabular}{|c|c|c|c|c|}
\hline Tests/Characteristics & $\begin{array}{l}\text { Escherichia } \\
\text { coli }\end{array}$ & $\begin{array}{c}\text { Pseudomonas } \\
\text { aeruginosa }\end{array}$ & $\begin{array}{l}\text { Klebsiella } \\
\text { sp. }\end{array}$ & $\begin{array}{c}\text { Enterococcus } \\
\text { sp. }\end{array}$ \\
\hline Cell shape & Rods & Rods & Rods & Coccus \\
\hline Gram reaction & - & - & - & + \\
\hline Motility & + & + & - & - \\
\hline Lipid hydrolysis & - & + & + & + \\
\hline Starch hydrolysis & - & + & - & + \\
\hline Casein hydrolysis & - & - & - & + \\
\hline Catalase test & + & + & + & - \\
\hline Oxidase test & - & + & - & - \\
\hline Urease test & - & - & + & - \\
\hline Growth on TSI & + & - & - & + \\
\hline Nitrate reduction test & + & + & + & + \\
\hline Indole production test & + & - & - & + \\
\hline Methyl red test & + & + & - & - \\
\hline Voges-proskauer test & - & - & + & + \\
\hline Citrate utilization test & - & + & + & + \\
\hline \multicolumn{5}{|c|}{ Carbohydrate utilization tests } \\
\hline Glucose & + & + & + & + \\
\hline Fructose & + & + & + & + \\
\hline Lactose & + & - & + & + \\
\hline Mannitol & + & - & + & + \\
\hline Sorbitol & - & - & + & + \\
\hline
\end{tabular}

- Indicates negative results and + indicates positive results

Based on the antimicrobial susceptibility test, ampicillin showed lowest degree of MIC value against Pseudomonas aeruginosa but highest degree of MIC value against Klebsiella sp $(800 \mu \mathrm{g} / \mathrm{ml})$. In the other hand, E. coli was inhibited by ciprofloxacin $(300 \mu \mathrm{g} / \mathrm{ml})$. In case of streptomycin showed highest inhibition activity against Klebsiella sp (300 $\mu \mathrm{g} / \mathrm{ml})$. Enterococcus sp is inhibited by chloramphenicol (Table 3). 
Table 3. Antimicrobial susceptibility test against isolated pathogens.

\begin{tabular}{lcccc}
\hline Antibiotics & \multicolumn{4}{c}{ MIC value of tests bacteria $(\mu \mathrm{g} / \mathrm{ml})$} \\
\cline { 2 - 5 } & Escherichia coli & $\begin{array}{c}\text { Pseudomonas } \\
\text { aeruginosa }\end{array}$ & Klebsiella sp. & Enterococcus sp. \\
\hline Ampicillin & 500 & 50 & 800 & 500 \\
Amoxicillin & 500 & 500 & 800 & 500 \\
Chloramphenicol & 500 & 800 & 500 & 300 \\
Ciprofloxacin & 300 & 800 & 500 & 800 \\
Streptomycin & 500 & 500 & 300 & 800 \\
\hline
\end{tabular}

Leaves of Tamarindus indica was extracted for evaluation of antimicrobial activity against UTI pathogens. Antibacterial activity of different solvent extract of $T$. indicus leaves on the different bacteria is given in Table 4. Results showed that Acetone extracts has greater antibacterial activity among all the extracts its maximum value of the zone of the inhibition is noted against $E$. coli $(22.5 \mathrm{~mm})$. Only methanol extracts of leaves showed activity against $P$. aeruginosa $(14.7 \mathrm{~mm})$. Chloroform extracts was showed activity against Klebsiella sp. $(6.2 \mathrm{~mm})$.

Table 4. Diameter of zone of inhibition of various solvent extracts of Tamarindus indica leaves shown against UTI causing bacteria.

\begin{tabular}{|c|c|c|c|c|}
\hline \multirow[t]{2}{*}{ Tested bacteria } & \multicolumn{4}{|c|}{ Zone of inhibition (mm) } \\
\hline & Chloroform & Methanolic & Acetone & Aqueous \\
\hline Escherichia coli & 0 & 0 & 22.5 & 10 \\
\hline Pseudomonas aeruginosa & 0 & 14.7 & 0 & 8 \\
\hline Klebsiella sp. & 6.2 & 17.5 & 18 & 0 \\
\hline Enterococcus sp. & 0 & 21.4 & 16 & 0 \\
\hline
\end{tabular}

Fig. 2a. Zone of inhibition of acetone extracts of $T$. indica leaves; Fig. 2b. Zone of inhibition of methanol extracts of $T$. indica leaves. 
MIC value of plant extracts of different solvents is showed in Fig. 3. Highest MIC value of acetone extracts of the plant is showed $1000 \mu \mathrm{g} / \mathrm{ml}$ against Klebsiella sp. Lowest degree of MIC value of methanol extracts is showed against Enterococcus sp.

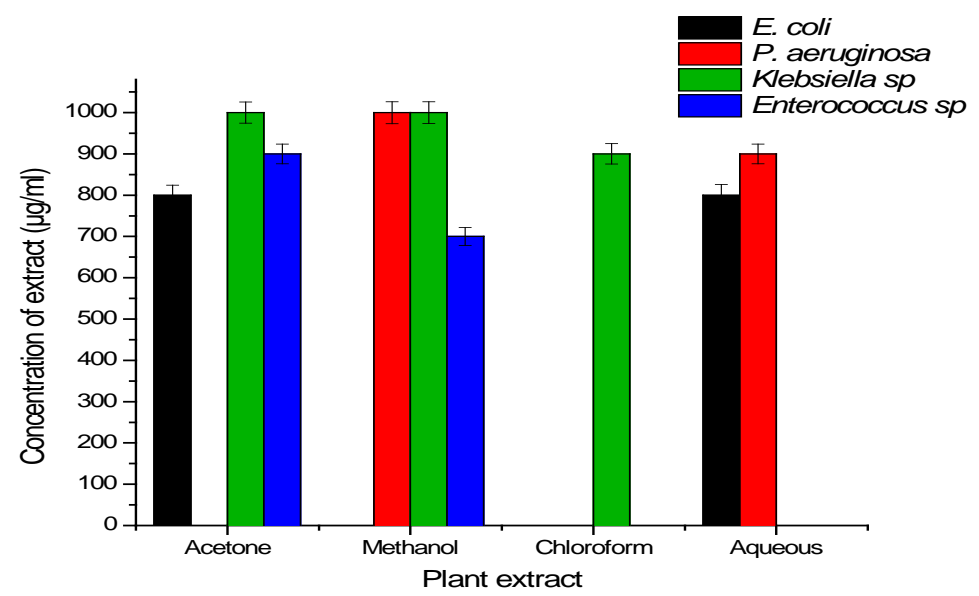

Fig. 3. MIC value of plant extracts.

Phytochemical constituents present in the plant extract included alkaloids, tannins, flavonoids, sesquiterpenes, carbohydrates, saponins, phlobatannins and anthocyanins (Table 5).

Table 5. Phytochemical screening of $T$. indicus leaves extract.

\begin{tabular}{cc}
\hline Secondary metabolites & Methanolic leaves extracts \\
\hline Alkaloids & + \\
Tannins & + \\
Steroids & - \\
Cardiac glycosides & - \\
Flavonoids & + \\
Terpenoids & - \\
Sesquiterpenes & + \\
Carbohydrates & + \\
Saponins & + \\
Phlobatannins & + \\
Anthocyanins & + \\
\hline
\end{tabular}




\section{Discussion}

Bioactive constituents such as flavonoids, alkaloids, tannins and several other aromatic compounds serve as defense mechanisms in the plant against microorganisms (Lutterodt et al. 1999, Bonjar et al. 2004). The presence of antibacterial activity against Gram positive as well as Gram negative bacteria might be indicative of the occurrence of broad spectrum antibiotic compounds (Srinivasan et al. 2001b, Vaghasiya and Chanda 2007). This will be advantageous to fight the menace of antibiotic refractive pathogens which are very much prevalent in recent times. The results showed that acetone extracts of leaves are more effective both Gram positive bacteria and Gram negative bacteria. Different organic solvents have been reported to have the capability to extract different phytochemicals based on their polarity or solubility in the solvent (Marjorie 1999). Same results had been reported by Doughari (2006). Acetone extracts of leaves might have higher solubility for more phytochemicals, consequently the highest antibacterial activity. The occurrence of antimicrobial activity by aqueous extracts provides the scientific basis for using this plant in the traditional treatment of diseases. The highest MIC values of Enterococcus sp. is an indication that either the methanol plant extracts are more effective on Gram positive bacteria or that the organism possesses the capability of acquiring antibiotic resistance, while the low MIC values for other bacteria indicates the potentiality of the plant extracts.

\section{Conclusion}

From the above results we can conclude that plants have remarkable antimicrobial activity as compare to antibiotic activity. Organisms are gaining resistance day by day towards the antibiotics, so that some natural product should be needed to overcome these antibiotic resistant organisms. Moreover plants have no side effect. The antibacterial activity of leaf extract of $T$. indica might help to discover new antimicrobial phytochemical which might serve as selective agents for controlling infectious diseases. This work has opened up the possibility of using this plant in the treatment of urinary tract infections in near future. However, the chemical nature of bioactive compounds and their further purification needs to be carried out.

\section{Acknowledgement}

This project is supported by a SoRF fellowship internship mode (NASI/SoRF-I/2014-2015/70) from Department of Science and Technology, Govt. of India, New Delhi. We are grateful to Prof. Chandan Sengupta, Head, Department of Botany, University of Kalyani for providing facilities to perform this work.

\section{References}

Bonjar GHS, Aghighi S and Nik AK (2004). Antibacterial and antifungal survey in plants used in indigenous herbal medicine of south east regions of Iran, Journal of Biological Science 4(3): 405-412.

Doughari JH (2006). Antimicrobial activity of Tamarindus indica Linn, Tropical Journal of Pharmaceutical Research 5(2): 597-603.

El-Siddig K, Gunasena HPM, Prasad BA, Pushpakumara DK, Ramana KVR, Vijayanand P and Williams JT (2006). Tamarind. Tamarindus indica. Southampton, UK.

Escalona-Arranz JC, Péres-Roses R, Urdaneta-Laffita I, Camacho-Pozo MI, Rodríguez-Amado J and Licea-Jiménez I (2010). Antimicrobial activity of extracts from Tamarindus indica L. leaves, Pharmacognosy Magazine 6(23): 242247.

Geetha RV, Roy A and Lakshmi T (2011). Nature's weapon against urinary tract infections, International Journal of Drug Development and Research 3(3): 85-100. 
Gumgumjee N, Khedr A and Hajar A (2012). Antimicrobial activities and chemical properties of Tamarindus indica L. leaves extract, African Journal of Microbiology Research 6: 6172-6181.

Harborne JB (1998). Phytochemical methods - a guide to modern techniques of plant analysis. Chapman and Hall, London.

Holt JG, Krieg NR, Sneath PHA, Stanley JT and Williams ST (1994). Bergey's Manual of Determinative

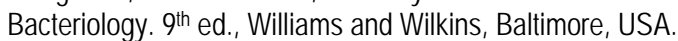

Joyeux M, Mortier F and Flurentin J (1995). Screening of antiradical, antilipoproxidant and hepatotoprotective effects of nine plant extracts used in Caribbean folk medicine, Phytotherapy Research 9: 228-230.

Kebira AN, Ochola P and Khamadi SA (2009). Isolation and antimicrobial susceptibility testing of Escherichia coli causing urinary tract infections, Journal of Applied Bioscience 22: 1320-1325.

Khanzada SK, Shaikh W, Sofia S, Kazi TG, Usmanghani K, Kabir A and Sheerazi TH (2008). Chemical constituents of Tamarindus indica L. medicinal plant in Sindh, Pakistan Journal of Botany 40(6): 2553-2559.

Lai PK and Roy J (2004). Antimicrobial and chemopreventive properties of herbs and spices, Current Medicinal Chemistry 11(11): 1451-1460.

Lutterodt GD, Ismail A, Basheer RH and Baharudin HM (1999). Antimicrobial effects of Psidium guajava extracts as one mechanism of its antidiarrhoeal action, Malaysian Journal of Medical Science 6(2): 17-20.

Marjorie MC (1999). Plant products as antimicrobial agents, Clinical Microbiology Review 12(4): 564-582.

National Committee for Clinical Laboratory Standards (1993). Methods for dilution in antimicrobial susceptibility tests: approved standard M2-A5, National Committee for Clinic: Laboratory Standards, Vilanova, P.A.

Nwodo UU, Obiiyeke GE, Chigor VN and Okoh Al (2011). Assessment of Tamarindus indica extracts for antibacterial activity, International Journal of Molecular Sciences 12(10): 6385-6396.

Saeed S and Tariq P (2008). In vitro antibacterial activity of clove against Gram negative bacteria, Pakistan Journal of Botany 40(5): 2157-2160.

Schappert SM and Rechtsteiner EA (2008). Ambulatory medical care utilization estimates for 2006. National Health Statistics Reports; No. 8. Hyattsville, MD: National Center for Health Statistics.

Sethi S and Gupta S (2013). A review: urinary tract infection and its treatment naturally, Phytomedicine 1(1): 34-39.

Souza-Fagundes EM, Queiroz AB, Martins Filho OA, Gazzinelli G, Corrêa-Oliveira R, Alves T and Zani CL (2002). Screening and fractionation of plant extracts with antiproliferative activity on human peripheral blood mononuclear cells, Memórias do Instituto Oswaldo Cruz 97(8): 1207-1212.

Srinivasan D, Nathan S, Suresh T and Lakshmanaperumalsamy P (2001a). Antibacterial activity of neem (Azadirachta indica) and tamarind (Tamarindus indica) leaves. Asian Journal of Microbiology Biotechnology 3(1): 67-73.

Srinivasan D, Nathan S, Suresh T and Perumalsamy PL (2001b). Antimicrobial activity of certain Indian medicinal plants used in folkloric medicine, Journal of Ethnopharmacology 74(3): 217-220.

Stockwell C (1988). Nature's Pharmacy, Century Hutchinson Ltd., London, UK.

Thomson WAR (1978). Medicines from the earth, McGraw-Hill Book Co. Maidenhead, UK.

Vaghasiya $Y$ and Chanda SV (2007). Screening of methanol and acetone extracts of fourteen Indian medicinal plants for antimicrobial activity, Turkish Journal of Biology 31: 243-248. 
Biswas et al. 